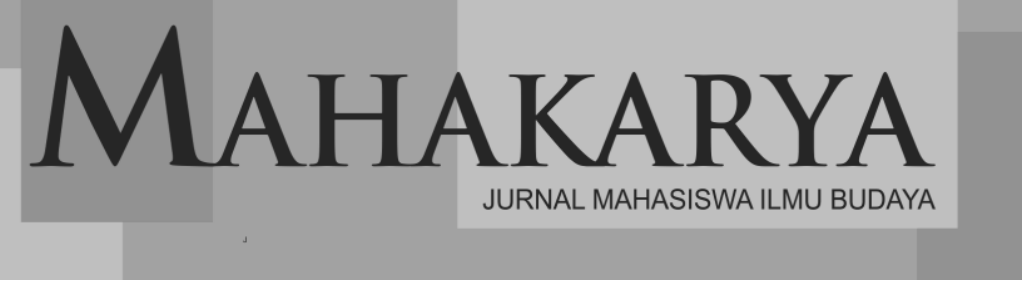

E-ISSN: 2798-0960 P-ISSN: 2798-0987

Volume 2 Nomor 1 - Juni 2021

\title{
CITRA WANITA ARAB DAN EROPA DALAM NOVEL ILLA FATIMAH KARYA ANIS MANSOUR: KRITIK SASTRA FEMINIS
}

\author{
Hermawati Putri Dian Insani \\ hermawati.putri.d@mail.ugm.ac.id \\ Program Studi Magister Kajian Budaya Timur Tengah \\ Universitas Gadjah Mada \\ Yogyakarta
}

\begin{abstract}
This study examined the images of Arabian and European women in the novel Illa Fatimah written by Anis Mansour. To describe the women's images, this study applied structural analysis method and ideologist feminism literature criticism approaches. It as intended to reveal the female characters and stereotypes in the novel The method of this research was descriptive-qualitative since the data of this study were textual in the forms of words, phrases, clauses, sentences showing the intrinsic and extrinsic elements of the novel. The result of this study showsthat there are some differences between Arabian and European woman images both in physical and psychological aspects as well as in their families and communities.
\end{abstract}

Keywords: woman, Arabic, Europe, feminism literary criticism

\section{PENDAHULUAN}

Karya sastra merupakan karya imajinatif ciptaan manusia yang bersifat kreatif estetik. Karya sastra juga menampilkan gambaran kehidupan. Artinya, gambaran kehidupan manusia dituliskan dalam karya sastra. Hal ini sebagaimana dijelaskan oleh Plato (429347 SM), bahwa karya sastra merupakan mimetik atau tiruan orientasi alam semesta. Karya sastra bukan hanya sekadar hiburan, tetapi juga berisi pendidikan dan moral yang digambarkan melalui sikap maupun perilaku tokoh-tokoh dalam cerita tersebut (Teeuw 1984, 219). Jadi, ada hubungan antara sastra yang diciptakan pengarang (melalui imajinasi dan pemahamannya terhadap apa yang terjadi di masyarakat) dengan normanorma dan nalar kolektif masyarakat tempat sastrawan dan pembaca hidup. Melalui karya sastra, diungkapkan norma-norma dan nalar kolektif masyarakat yang melahirkan karya tersebut.

Norma dan nalar kolektif masyarakat Mesir digambarkan oleh sastrawansastrawan Mesir melalui karya sastra mereka. Salah satu tema yang banyak diangkat oleh sastrawan Mesir adalah tema budaya patriarki. Budaya tersebut memberikan otoritas dan dominasi kepada laki-laki dalam kehidupan bermasyarakat. Laki-laki pada umumnya mendapatkan kesempatan yang lebih besar daripada perempuan untuk memperoleh prestasi dalam masyarakat. Budaya ini menjadikan wanita diremehkan oleh laki-laki (Omara, tanpa tahun, 148). Di antara sastrawan Mesir yang mengangkat budaya patriarki adalah Anis Mansour.

Karya sastra Anis Mansour sudah diteliti oleh beberapa peneliti, seperti cerpen "Fatatun min Dimasyqa" dalam antologi Alwanun min al-Hubbi yang telah diteliti oleh Ashidqy (2017) dan cerpen "Garamun fii at-Tilifun" dalam antologi cerpen Qulubun Sagiratun yang telah diteliti oleh Fauziyah (2015). Tokoh wanita dalam kedua cerpen tersebut cenderung mendapatkan diskrimasi, stereotipe, dan ketidakadilan gender. Namun, tidak semua karya Anis Mansour mengangkat tema budaya patriarki. Ada juga yang mengangkat tema citra tokoh wanita. Salah satu novel karya Anis Mansour yang mengangkat tema citra wanita adalah novelnya yang berjudul Illa Fatimah (1994) yang dijadikan objek material penelitian ini. 
Ada beberapa alasan yang melatarbelakangi pemilihan novel Illa Fatimah karya Anis Mansour sebagai objek material dalam penelitian ini. Pertama, sejauh pengamatan yang telah dilakukan, novel ini memiliki tema yang berbeda dengan novel-novel Anis Mansour lainnya. Novel ini cenderung menggambarkan tokoh-tokoh wanita yang tidak mendapatkan perlakuan subordinasi, stereotipe, dan ketidakadilan gender, tetapi memiliki peran yang sama dengan laki-laki.

Kedua, novel Illa Fatimah ditulis Anis Mansour setelah melakukan perjalanan ke beberapa negara di benua Eropa, seperti Amerika, Inggris, Spanyol, dan Austria pada tahun 1953 yang merupakan negara Eropa (Egypt Independent, 2020). Perjalanan tersebut memberikan pengalaman bagaimana citra wanita Eropa yang melatarbelakangi penulisan novel tersebut.

Ketiga, walaupun tokoh utama dalam novel Illa Fatimah adalah laki-laki, tokohtokoh wanita yang digambarkan dalam novel tersebut memiliki karakter kuat dan berperan aktif dalam kehidupan sehari-hari tokoh utama laki-laki. Karakter tersebut menggambarkan bagaimana citra wanita yang ditawarkan oleh Anis Mansour dalam novel tersebut.

Keempat, dalam biografi dan riwayat karyanya, Anis Mansour merupakan seorang sastrawan dan salah satu tokoh yang mendukung gerakan feminisme di Mesir yang merupakan salah satu negara Arab (Egypt Independent, 2020).

Beberapa alasan di atas menunjukan bahwa analisis citra wanita dalam novel Illa Fatimah karya Anis Mansour cukup menarik untuk dilakukan. Untuk mengungkapkan citra wanita dalam novel ini, digunakan analisis stuktural yang dilengkapi dengan analisis kritik sastra feminis, dengan tekanan pada citra wanita melalui sikap dan karakter tokoh wanita dalam novel tersebut.

\section{Teori Struktural}

Teeuw $(1984,135)$ menyatakan bahwa teori struktural merupakan kajian yang hanya membahas karya sastra secara otonom, karya sastra yang melepaskan aspek-aspek di luarnya dengan menganalisis unsur-unsur yang ada di dalamnya. Teori ini membagi unsur-unsur instrinsik dalam karya sastra menjadi tokoh, penokohan, latar, sudut pandang, dan alur sehingga dapat dipaparkan secermat mungkin fungsi dan keterkaitan unsur karya sastra yang secara bersama menghasilkan makna yang menyeluruh (Nurgiyantoro 1996, 37).

Penelitian mengenai citra wanita Arab dan Eropa ini hanya memanfaatkan teori struktural dalam hubungannya dengan analisis tokoh dan penokohan sebagai dasar analisis kritik sastra feminis yang dikhususkan kepada citra tokoh wanita dalam novel Illa Fatimah. Hal ini sesuai dengan pernyataan Djajanegara (200, 51-53) bahwa langkah pertama yang digunakan dalam identifikasi kritik sastra feminis adalah mengidentifikasi tokoh dan penokohan.

Tokoh dapat dipahami sebagai seseorang yang memiliki sejumlah kualifikasi mental dan fisik yang membedakannya dengan orang lain. Melalui kualifikasi tersebut, ditampilkan macam-macam perwatakan serta identifikasi apakah tokoh itu sebagai tokoh utama atau tambahan (Lukens dalam Nurgiyantoro 1996, 75).

Tokoh utama adalah tokoh yang diutamakan penceritaannya dalam novel yang bersangkutan. Ia merupakan tokoh yang paling banyak diceritakan, baik sebagai pelaku kejadian maupun yang dikenai kejadian. Bahkan, pada novel-novel tertentu, tokoh utama senantiasa hadir dalam setiap kejadian dan dapat ditemui dalam tiap halaman buku cerita yang bersangkutan, sedangkan tokoh tambahan adalah tokoh yang digambarkan lebih sedikit dibandingkan dengan tokoh utama. Tokoh tambahan akan dimunculkan jika kejadian dalam sebuah cerita secara langsung berkaitan dengan tokoh utama (Nurgiyantoro 1996, 258).

Jones (dalam Nurgiyantoro 1996, 165) mengemukakan bahwa penokohan adalah pelukisan gambaran yang jelas tentang seseorang yang ditampilkan dalam sebuah cerita. Istilah penokohan tidak hanya mencakup karakter, sifat, dan sikap untuk menampilkan kualitas pribadi tokoh cerita tetapi sekaligus mencakup masalah siapa tokoh cerita, 
bagaimana karakter, dan bagaimana penempatan dan pelukisannya dalam sebuah cerita sehingga bisa memberikan gambaran yang jelas kepada pembaca.

Menurut Wiyatmi (2009, 51), penokohan dapat dianalisis dengan tiga dimensi, yaitu fisiologis yang meliputi usia, jenis kelamin, keadaan tubuh, ciri-ciri muka, dan warna kulit; sosiologis yang meliputi status sosial, pekerjaan, jabatan, peran di dalam masyarakat, pendidikan, agama, pandangan hidup, ideologi, aktivitas sosial, organisasi, hobi, bangsa, suku, dan keturunan; serta psikologi yang meliputi mentalitas, keinginan, perasaan pribadi, sikap, kelakuan, dan intelektual

\section{Kritik Sastra Feminis Ideologis}

Kritik sastra feminis merupakan salah satu disiplin ilmu kritik sastra yang lahir sebagai respon atas berkembangluasnya feminisme di berbagai penjuru dunia. Menurut Wedon (dalam Sugihastuti \& Suharto 2016, 6) kritik sastra feminis adalah politik; sebuah politik yang secara langsung mengubah hubungan kekuatan kehidupan antara laki-laki dan wanita dalam masyarakat. Kekuatan ini terdiri dari struktur kehidupan, segi-segi kehidupan, keluarga, pendidikan, kebudayaan, dan kekuasaan. Segi-segi kehidupan tersebut menentukan siapa, apa, dan untuk siapa, serta akan menjadi apa perempuan tersebut. Kekuatan tersebut dapat dikaji dengan menganalisis citra wanita yang ada dalam karya sastra.

Citra wanita menjadi salah satu unsur objek dalam penelitian kritik sastra feminis. Citra (image) menurut Sudjiman $(1986,17)$ dalam Kamus Istilah Sastra adalah kesan mental atau bayangan visual yang ditimbulkan oleh sebuah kata, frasa, atau kalimat. Selain itu, Sugihastuti $(2000,7)$ mengutip pengertian citra wanita yang dikemukakan oleh Pradopo sebagai semua gambaran mental spiritual dan tingkah laku keseharian wanita yang menunjukan ciri khas wanita. Berdasarkan pengertian tersebut, citra wanita berarti gambaran yang berkaitan dengan seorang tokoh wanita, baik dari segi fisik, psikologis, maupun kedudukaannya, dalam sebuah karya sastra.

Citra wanita dibedakan menjadi dua, yaitu citra diri wanita dan citra sosial wanita. Citra diri wanita merupakan keadaan dan pandangan wanita yang berasal dari dalam dirinya sendiri yang terdiri dari dua aspek, yaitu aspek fisik dan aspek psikis (Sugihastuti 2000, 112-113). Secara fisik, wanita dewasa merupakan sosok individu hasil bentukan proses biologis dari bayi perempuan yang usianya telah mencapai taraf dewasa. Pada taraf dewasa, wanita dicirikan dengan tanda-tanda tertentu, yaitu dialaminya haid dan perubahan-perubahan fisik lainnya, seperti tumbuhnya bulu-bulu di bagian badan tertentu, suara, dan lainnya. Selain itu, wanita adalah makhluk yang khas dan memiliki sesuatu yang tidak dimiliki laki-laki, di antaranya dapat hamil, melahirkan, dan menyusui anak-anaknya. Oleh karena itu, wanita dianggap sebagai sumber kehidupan karena dapat menciptakan makhluk baru dalam artian melahirkan anak (Sugihastuti 2000, 112).

Sementara itu, secara psikis, wanita adalah makhluk yang berpikir, berperasaan, dan beraspirasi (Sugihastuti 2000, 95). Aspek psikis wanita, sesuai dengan prinsip feminitas, adalah keterhubungan, penerimaan, cinta kasih, pengasuhan berbagai potensi hidup, orientasi yang komulan, dan pemeliharaan hubungan interpersonal. Aspek psikis ini dan aspek fisik saling mempengaruhi dan keduanya juga merupakan aspek yang berpengaruh pada citra diri wanita. Semakin dewasa fisik wanita akan semakin berkembang pula psikisnya menjadi lebih dewasa (Sugihastuti 2000, 95-96).

Citra sosial wanita merupakan citra wanita yang erat hubungannya dengan norma yang berlaku dalam sebuah kelompok masyarakat, tempat wanita menjadi anggota dan berhasrat mengadakan hubungan antarmanusia. Misalnya dalam sebuah keluarga, wanita berperan sebagai istri, ibu, atau sebagai anggota keluarga yang masing-masing menimbulkan sikap sosial. Citra sosial wanita juga merupakan masalah pengalaman diri. Pengalaman inilah yang menentukan interaksi sosial wanita dalam masyarakat termasuk terhadap laki-laki (Sugihastuti 2000, 144). Citra wanita dalam aspek sosial ini dibagi menjadi dua, yaitu citra wanita dalam keluarga dan citra wanita dalam masyarakat (Sugihastuti 2000, 143). 
Citra wanita dalam keluarga berarti peran wanita dalam keluarga. Artinya, wanita digambarkan sebagai wanita dewasa, seorang istri, dan seorang ibu rumah tangga. Citra wanita dalam keluarga juga menggambarkan wanita sebagai insan yang secara ekonomis tergantung pada laki-laki karena pekerjaan yang dilakukannya tidak menghasilkan uang, serta mengembangkan fungsi khusus sesuai dengan aspek fisik dan psikis (Sugihastuti 2000, 125). Adapun citra wanita dalam masyarakat berarti peran wanita dalam masyarakat. Wanita digambarkan sebagai makhluk sosial yang membutuhkan orang lain dalam kehidupannya. Hubungan wanita dengan orang lain ini dapat bersifat umum atau khusus. Hubungan tersebut bisa antara sesama wanita atau dengan laki-laki (Sugihastuti 2000, 142).

\section{Biografi Anis Mansour}

Anis Mansour, penulis novel Illa Fatimahyang menjadi objek material penelitian ini, merupakan sastrawan Mesir yang bekerja sebagai seorang jurnalis dan penerjemah. Ia lahir di Desa Kafr El-Baz, pada 18 Agustus 1924. Anis Mansour meninggal pada usia 87 di Kairo pada 21 Oktober 2011. Ia wafat setelah mengidap penyakit paru-paru dan nyeri akut di punggung (Revolvy 2020).

Pada usia delapan tahun, Anis Mansour sudah mengikuti kelompok penulis desa dan menghafal Al-Qur'an. Ia memulai pendidikannya di Sekolah Dasar Abu Homs dan lulus dari sekolah menengah atas di Mansoura pada tahun 1943. Setelah lulus sekolah menengah, ia melanjutkan jenjang pendidikannya di Fakultas Filsafat Universitas Kairo pada tahun 1947 (Ayyaz, tanpa tahun, 1).

Setelah menyelesaikan perkuliahannya, Anis Mansour bekerja sebagai dosen ilmu filsafat modern di Fakultas Sastra Universitas Ain Shams pada tahun 1954 sampai tahun 1963. Selain menjadi dosen, ia juga bekerja sebagai pemimpin redaksi beberapa majalah ternama di Mesir, seperti al-Jailu dan majalah wanita Hiya. Beberapa tahun kemudian ia bergabung dengan staf surat kabar al-Asas, Rasa il al-Yusuf, dan al-Ahram. Selanjutnya, ia menjabat sebagai kepala editor majalah Akhir Sa'ah dari tahun 1970 sampai dengan 1976 (Up Closed, 2020).

Pada tahun 1952, majalah mingguan Rasa il al-Yusuf menugaskan Anis Mansour melakukan perjalanan untuk mengikuti berita Raja Farouk yang lengser dari jabatannya. Selama 225 hari, ia melakukan perjalanan melintasi berbagai benua yaitu Asia, Amerika, dan Australia. Ia berhasil menjadi jurnalis pertama yang mewawancarai tokoh-tokoh internasional seperti Dalai Lama dan beberapa tokoh berpengaruh di dunia internasional (Egypt Independent, 2020).

Setelah melakukan perjalanan tersebut, Anis Mansour menyusun bukunya yang berjudul Kitabu Haula al-Alam 200 Yaumin pada tahun 1963. Buku ini mengungkapkan banyak fakta dan tradisi dari negara-negara yang dia kunjungi, termasuk India, Jepang dan Amerika Serikat, serta pertemuannya dengan Dalai Lama. Ia menulis novel ini karena terinspirasi dari novel karya Jules Verne, Around The World in Eighty Days yang terbit pada abad ke-19. Novel Kitabu Haula al-Alam 200 Yaumin telah dicetak ulang lebih dari 25 kali hingga saat ini. Para kritikus dan ilmuwan Mesir memberikan respon positif dan pujian terhadap buku ini (Egypt Independent, 2020).

Selain buku Kitabu Haula al-Alam 200 Yaumin, Anis Mansour telah menulis karya terjemahan populernya yang berjudul The 100: A Ranking of The Most Influential Persons in History karya Michael Hart tahun 1978. Terjemahan tersebut diremehkan oleh beberapa kritikus sastra karena ia telah menghapus beberapa paragraf dari teks aslinya. Mereka beranggapan bahwa terjemahannya tidak sesuai dengan metode penerjemahan yang semestinya (Egypt Independent, 2020).

Pada tahun 1994, Anis Mansour menulis novel yang berjudul Illa Fatimah. Anis Mansour menyempurnakan novel ini selama kurang lebih 20 tahun. Novel Illa Fatimah sudah ditayangkan di sinetron televisi pada tahun 1994. Novel ini menimbulkan banyak kontroversi karena seorang ekspatriat Mesir di Austria mengajukan gugatan terhadapnya dan menuduh melakukan plagiarisme. Namun, gugatan tersebut dihapuskan karena tidak ditemukan bukti (Egypt Independent, 2020). 
Karya Anis Mansour seluruhna berjumlah 185 buku, baik dalam bentuk puisi, cerpen, novel, maupun terjemahan. Topik karya Anis Mansour beragam, di antaranya perjalanan, sains, biografi, filsafat, dan politik. Karyanya banyak mengomentari tentang kritik feminis. Pandangan inilah yang banyak membuat karyanya ditentang. Namun, pertentangan ini tidak mempengaruhi minat baca masyarakat. Hal ini terbukti bahwa karya-karyanya tentang kritik sastra feminis sudah dicetak ulang sebanyak 30 kali (Egypt Independent, 2020).

Anis Mansour menerima banyak penghargaan, baik dari dalam maupun luar Mesir. Ia mendapatkan gelar guru besar dari Universitas Mansoura dan penghargaan motivator dari Dinas Kesenian, Sastra, dan Sosial pada tahun 1963. Pada tahun 1981, ia mendapatkan penghargaan Kreativitas Internasional yang Ketiga. Anis Mansour juga memenangkan penghargaan Emas dari salah satu saluran televisi Mesir selama empat tahun berturut-turut dan gelar Intelektual Arab pertama dari Yayasan Pemasaran Arab di London. Selain itu, ia juga menerima Hadiah Mubarak dalam kategori sastra dari Dewan Kebudayaan Tertinggi pada tahun 2001. Karena Hadiah Mubarak tersebut, didirikanlah sebuah monumen di kota Mansoura sebagai penghargaan yang tinggi kepada Anis Mansour (Aljazeera, 2020).

\section{Sinopsis Novel Illa Fatimah}

Novel Illa Fatimah karya Anis Mansour menceritakan tentang seorang pria bernama Sabir yang pergi ke Wina untuk mencari pekerjaan dan meninggalkan istrinya Tahani di Mesir. Di Wina, Sabir bertemu dengan seorang Mesir bernama Irfan ketika datang ke kota tempat banyak orang Mesir tinggal. Di sini Sabir bertemu dengan seorang wanita cantik bernama Margaret yang tak lama kemudian dinikahinya. Pasangan suami istri ini sangat bahagia. Sabir sangat mencintai Margaret, karena istri keduanya in berbeda dengan wanita-wanita lainnya. Margaret tidak suka mabuk-mabukan dan menggoda laki-laki Mesir seperti wanita-wanita Wina lainnya. Bahkan, ia rela masuk agama Islam demi menikah dengan Sabir dan mengganti namanya menjadi lebih Islami, yaitu Fatimah.

Sabir tidak memberi tahu Tahani bahwa dia telah menikahi Margaret. Temanteman Sabir, Badawi, Fauzi dan Irfan, menasihatinya untuk mempertimbangkan kembali keputusannya. Satu jam kemudian, sebuah pesan dari Mesir datang dan memberi tahukan bahwa Tahani telah meninggal karena gempa bumi.

Setelah kematian Tahani, ibu Sabir jatuh sakit. Oleh ibunya, Sabir diperinthkan untuk menikahi Majidah, putri bibinya, agar putranya bisa memperoleh kasih sayang dari seorang ibu. Sabir akhirnya menikah dengan Majidah tanpa seizin Margaret di Wina. Suatu hari, Margaret mengetahui bahwa Sabir telah menikah dengan seorang wanita di Mesir. Ia mendapatkan informasi ini dari percakapan Sabir di telepon beberapa waktu sebelumnya. Selanjutnya, Margaret sepakat untuk bercerai dari Sabir agar dirinya tidak mengganggu hubungan pernikahan antara Sabir dan Majidah.

Beberapa waktu kemudian, Margaret menikah dengan Dr. Hans Schlagel, teman lamanya di SMA. Margaret telah menentukan jalan hidupnya dan tampak bahagia dengan suami barunya. Sementara itu, Sabir dan Majidah tetap tinggal bersama di Wina. Mereka berdua hidup bahagia dengan anak kembarnya. Pada saat yang sama, Adilah, ibu Sabir, juga menikah dengan Abdul Latif, seorang Mesir yang sukses dan tinggal di Wina.

\section{METODE PENELITIAN}

Sesuai dengan landasan teori, metode yang digunakan untuk mengumpulkan dan mengolah data dalam penelitian ini adalah metode kualitatif. Dalam metode kualitatif, terdapat berbagai pendekatan berbeda. Dalam penelitian ini digunakan pendekatan deskriptif untuk menjelaskan bagaimana citra atau gambaran kehidupan dan perilaku wanita Arab dan Eropa dalam novel Illa Fatimah yng menjadi objek material penelitian..

Menurut, Sudaryanto $(2015,6)$ metode kualitatif dapat dibagi menjadi tiga tahap, yaitu penyediaan data, analisis data, dan penyajian hasil analisis data. Pada tahap penyediaan data, objek material yang telah ditentukan dibaca, diterjemahkan, lalu 
dikumpulkan data-datanya secara kualitatif. Sebagai data primer dalam penelitian ini adalah kata, frasa, klausa, dan kalimat yang berasal novel Illa Fatimah karya Anis Mansour yang menjadi sumber data penelitian. Sementara itu, data sekundernya berupa teori atau pendapat para ahli yang bersumber dari buku-buku referensi.

Setelah tahap penyediaan data selesai, selanjutnya dilakukan analisis data dengan tekanan pada tokoh dan penokohan yang tergambar dalam novel Illa Fatimah. Analisis tokoh dan penokohan ini dilakukan untuk mempermudah analisis selanjutnya, yakni kritik sastra feminis di dalam novel tersebut. Sesuai dengan pendapat Sugihastuti dan Suharto $(2016,72)$, dalam hal ini, tidak semua unsur struktur dianalisis sehingga hanya dipilih unsur-unsur tertentu yang membantu tercapainya tjuan penelitian. Analisis tokoh dan penokohan difokuskan kepada tokoh-tokoh wanita dan tokoh laki-laki yang membawa gagasan feminis dengan tokoh wanita.

Analisis tokoh dan penokohan yang telah dilakukan dalam penelitian sebelumnya dimanfaatkan untuk menganalisis citra wanita yang ada di dalam novel Illa Fatimah. Donovan (dalam Muslimat 1990, 264) menyatakan bahwa citra wanita atau images of women menentukan bagaimana karakter-karakter wanita dipresentasikan di dalam teks sastra. Asumsi utama yang harus dibuat dalam tahap ini adalah evaluasi otentisitas karakter-karakter wanita.Citra wanita yang didapatkan dari data yang telah dikumpulkan kemudian diklasifikasikan ke dalam citra diri wanita dan citra sosial wanita sebagaimana dirumuskan dalam teori yang menjadi landasan penelitian ini.

Selanjutnya, data-data yang telah dianalisis diolah dalam tahap penyajian hasil data. Pada tahap ini, hasil analisis data mengenai citra wanita akan menghasilkan gambaran mengenai ideologi citra wanita Arab dan Eropa. Ideologi inilah yang menjadi citra wanita ideal dari sudut pandang pengarang laki-laki novel Illa Fatimah, yaitu Anis Mansour.

\section{HASIL DAN PEMBAHASAN}

\section{Tokoh dan Penokohan}

Berdasarkan analisis tokoh dalam novel Illa Fatimah, tokoh utama dalam novel ini adalah seorang laki-laki bernama Sabir, Tokoh ini paling banyak diceritakan. Hal tersebut dibuktikan bahwa tokoh Sabir muncul dalam 99 halaman dari 111 halaman jumlah keseluruhan novel, sedangkan tokoh lain yang ada dalam novel maksimal muncul dalam 47 halaman. Selain itu, tokoh Sabir juga berhubungan secara langsung dengan semua tokoh tambahan yang ada, yaitu Irfan (halaman 10), Fauzi (44), Badawi (57), Abdul Latif (60), Margaret (16), Majidah (52), Tahani (15), Liliyan (46), dan Adilah (52).Sedangkan tokoh tambahan dalam novel Illa Fatimah adalah Irfan, Fauzi, Badawi, dan Abdul Latif sebagai tokoh tambahan laki-laki dan Margaret, Majidah, Tahani, Liliyan, dan Adilah sebagai tokoh tambahan wanita.

Pada penelitian ini, tidak semua tokoh dalam novel Illa Fatimah dianalisis penokohannya. Tokoh yang dianalisis penokohannya adalah tokoh utama,Sabir, tokoh tambahan laki-laki yang membawa ide feminis dengan tokoh wanita; Badawi, Fauzi, dan Abdul Latif serta semua tokoh tambahan wanita; Margaret, Majidah, Liliyan, Tahani, dan Adilah. Berikut analisis penokohan untuk masing-masing tokoh.

Sabir berusia sekitar 30 tahun, beragama Islam, religius, jujur, bertanggung jawab atas keluarganya dan dihormati oleh masyarakat. Badawi adalah pria Mesir, berusia sekitar 30 tahun, teman dekat Sabir, suka bermain-main dengan wanita, tetapi peduli dengan teman-temannya. Fauzi adalah pria Mesir yang lebih tua dari Sabir dan Badawi, teman dekat Sabir. Dia suka bermain dengan wanita, tetapi dia peduli dengan temantemannya. Abdul Latif digambarkan sebagai pria Mesir berusia sekitar 50 tahun, kaya, bertanggung jawab, tekun, cerdas, dan dihormati masyarakat.

Margaret adalah istri kedua Sabir. Dia adalah wanita Austria berusia 40 tahun, cantik, kaya, penuh hormat, baik, dan elegan. Sementara, Majidah adalah istri ketiga Sabir, putri bibi Sabir. Dia adalah seorang wanita Mesir sekitar 30 tahun, cantik, dan bertanggung jawab. Kemudian, Tahani adalah istri pertama Sabir dari Mesir. Dia adalah seorang wanita berusia sekitar 20 tahun, seorang wanita yang beragama islam, dan 
mudah cemburu. Selanjutnya, Adilah adalah ibu dari Sabir dan istri dari Abdul Latif. Dia adalah seorang wanita Mesir sekitar 50 tahun, baik, dan bijaksana. Sementara Liliyan adalah istri Fauzi, seorang wanita Austria, cantik, yang bekerja di dinas sosial dan peduli dengan teman-temannya.

\section{Citra Wanita dalam Novel Illa Fatimah}

Untuk keperluan analisis mengenai citra wanita, semua tokoh wanita dalam novel Illa Fatimah dilibatkan, yaitu Margaret, Majidah, Adilah, Tahani, dan Liliyan. Analisis citra wanita in diurutkan berdasarkan tingkat keeratan hubungan tokoh-tokoh wanita tersebut dengan tokoh utama laki-laki, yaitu Sabir yang dibuktikan dengan jumlah kemunculan masing-masing tokoh di dalam novel. Dari kriteria ini diperoleh urutan analisis tokh wanita sebagai berikut: Margaret (47 halaman), Majidah (23), Tahani (10), Adilah (9), dan Liliyan (4).

Tokoh tambahan laki-laki dalam novel tidak dibahas secara khusus dalam hubungannya dengan citra wanita. Akan tetapi, penokohan tokoh laki-laki dalam novel yang dihasilkan dari analisis struktural yang telah dibahas, yaitu Sabir, Badawi, Fauzi, dan Abdul Latief, dimanfaatkan untuk memperkuat analisis ide feminis tokoh wanita.

\section{Margaret}

Secara fisik, Margaret digambarkan sebagai seorang wanita berusia 40 tahun, berparas cantik dan mempesona, tetapi mandul. Ia memiliki bola mata biru dan wajah putih yang kemerah-merahan dan wajah yang mempesona ketika tertawa (Mansour, 1994, 22). Margaret tidak dikaruniai anak dari pernikahan sebelumnya (Mansour, 1994, 69). Walaupun tidak memiliki anak, Margaret memiliki naluri alamiah wanita, yaitu berjiwa keibuan. Jiwa keibuan Margaret ini tampak ketika ia menyambut Sabir yang baru saja kembali dari Mesir. Ia mengharapkan untuk bisa merawat dan mengasuh anak Sabir di Wina (Mansour 1994, 62).

Secara psikologis, Margaret mampu berpikir secara sistematis. Ia dapat menyusun perabotan rumahnya dengan bersih, tertib, elok dan indah walaupun sederhana. Ia menghiasi rumahnya dengan bunga-bunga yang indah (Mansour, 1994, 24). Margaret juga merupakan tokoh wanita yang berperasaan. Ia menganggap masyarakat Mesir sebagai saudara sendiri dan tidak segan-segan membantu mereka (Mansour, 1994:16). Selain itu, ia sangat mencintai suaminya, yaitu Sabir. Karena rasa cintanya yang mendalam, ia merasakan gejolak dalam hatinya ketika ia memperhatikan mimik dan cara bicara Sabir ketika ia menelepon Adilah dan merasakan bahwa Sabir telah menikah selama ia kembali ke Mesir (Mansour 1994, 68).

Apabila dipandang citra sosial wanita dalam keluarga, Margaret yang merupakan istri kedua Sabir merupakan wanita yang kaya-raya sehingga tidak menggantungkan kehidupannya secara ekonomis kepada laki-laki dan dapat mengurus rumah tangga dengan baik. Margaret menikah dengan Sabir dan masuk agama Islam. Ia menjadi seorang mualaf karena kecintaannya kepada Sabir yang merupakan orang yang taat beragama. Bahkan, ia mencari dan mengganti namanya menjadi lebih Islami, yaitu Fatimah (Mansour 1994, 66-67).

Dalam kaitannya dengan kehidupan wanita di masyarakat, Margaret dicitrakan sebagai seorang wanita Eropa yang kaya raya dan dihormati oleh masyarakat. Margaret dianggap sebagai wanita terhormat karena kekayaannya serta karakter dan sikapnya yang berbeda dari wanita-wanita Eropa pada umumnya yang suka makan bersama dan minum bir setiap malam. Ia hanya sedikit minum bir dan tidak pernah mabukmabukkan sehingga tidak ada orang yang berani menggoda atau mengganggunya (Mansour 1994, 23). Margaret juga dihormati karena kebaikan hatinya kepada orangorang Mesir yang kesusahan yang dianggapnya sebagai saudara sendiri (Mansour 1994, 23).

Majidah

Majidah digambarkan sebagai sosok wanita yang berusia sekitar 30 tahun dan berwajah cantik dengan bola mata berwarna hijau, hidung kecil, dan rambut pirang (Mansour, 
1994, 53). Majidah juga digambarkan sebagai seorang ibu karena diceritakan ia telah mengandung dan melahirkan bayi kembar dari pernikahannya dengan Sabir (Mansour, 1994, 111).

Majidah juga digambarkan sebagai makhluk psikologis, yaitu wanita mampu berpikir dan memiliki perasaan. Ia adalah wanita yang mampu berpikir karena sikapnya yang bertanggung jawab terhadap anak laki-laki tirinya, yaitu Hammadah. Ia rela bekerja siang dan malam untuk merawat dan mengasuh Hammadah (Mansour, 1994:53). Sementara itu, karakter Majidah sebagai sosok yang memiliki perasaan yang sensitif terlihat pada saat ia mengalami gejolak yang berat ketika mengetahui Sabir telah menikah dengan Tahani di Mesir dan dengan Margaret pada saat Sabir pergi ke Wina. Ia rela menjadi istri kedua setelah Tahani, istri pertama Sabir, dinyatakan meninggal dunia (Mansour 1994, 73).

Majidah yang berasal dari Mesir pergi ke Wina setelah beberapa saat menikah dan menjadi istri ketiga Sabir. Ia hidup dalam keluarga yang harmonis bersama suaminya. Hal ini tampak dari kesetiaannya untuk ikut Sabir pindah ke Wina bersama Adilah, ibu Sabir. Ia juga selalu mengikuti Sabir kemana pun suaminyaa pergi. Salah satunya ketika ada makan malam atau pesta perayaan pernikahan antara Margaret dengan Hans (Mansour 1994, 100).

Secara sosial, Majidah juga dicitrakan sebagai wanita yang dihormati di masyarakat. Hal ini dibuktikan ketika ia memutuskan untuk pergi ke Wina setelah menikah dengan Sabir, yang dikenal oleh masyarakat sebagai orang yang taat beragama, dan disambut dengan meriah oleh beberapa orang Mesir yang membawa rangkaian bunga sebagai ucapan selamat datang kepadanya (Mansour 1994, 82).

\section{Tahani}

Tahani,adalah seorang wanita yang usianya lebih muda daripada Sabir (Mansour, 1994, 16). Tahani juga digambarkan sebagai seorang ibu karena ada cerita ketika ia sedang mengandung anak pertamanya (Mansour 1994, 7) yang berusia tujuh bulan ketika Sabir sedang pergi ke Wina untuk mencari pekerjaan (Mansour, 1994, 36). Tahani kemudian merawat dan membesarkan anaknya sendirian sampai ia meninggal dunia karena gempa (Mansour 1994, 50-51).

Secara psikologis, Tahani dicitrakan sebagai seorang wanita yang bisa berpikir dan memiliki perasaan. Ia adalah wanita yang menyayangi suaminya, Sabir. Meskipun demikian, Tahani adalah orang yang mudah cemburu. Sifat ini tampak ketika ia membaca beberapa surat yang dikirimkan Sabir kepadanya. Sabir banyak bercerita tentang wanita-wanita yang ia temui di Wina. Cerita-cerita ini membuat Tahani jadi cemburu kepada Sabir. Akan tetapi, ia tidak berani mengungkapkan kecemburuannya ini secara langsung kepada Sabir (Mansour 1994, 32).

Tahani yang merupakan istri pertama Sabir adalah wanita Mesir yang taat beragama Islam dan dicitrakan sebagai seorang istri dalam keluarga yang harmonis (Mansour, 1994, 15-16). Tahani adalah seorang wanita yang mengurus kehidupan rumah tangga, tidak bekerja, serta tidak menghasilkan uang sehingga menggantungkan kehidupannya secara ekonomis kepada laki-laki. Tahani hanya mengurus suami dan anak-anak di rumah dan sempat ditinggal oleh Sabir ke luar negeri untuk mencari pekerjaan (Mansour 1994, 50).

\section{Adilah}

Adilah adalah ibu Sabir. Adilah merupakan sosok wanita yang sudah tua, berumur sekitar 50 tahun, dan sakit-sakitan. Ia juga diceritakan sebagai seorang ibu yang mampu mengasuh anak dengan baik. Ada beberapa alasan yang mendasari pernyataan ini. Pertama, Adilah diceritakan sebagai wanita yang mengandung dan melahirkan Sabir secara prematur ketika umur kandungannya baru tujuh bulan sehingga ia nyaris meninggal karenanya (Mansour 1994, 50). Kedua, Adilah bercerai dengan suaminya ketika Sabir berumur satu tahun karena permasalahan keluarga. Meskipun demikian, Adilah bisa membesarkan, mendidik, dan merawat anaknya sendirian. Sabir tumbuh 
menjadi seorang laki-laki dewasa yang mampu bekerja, taat beragama, dan kemudian bisa menikah (Mansour 1994, 50).

Secara psikologis, Adilah juga mampu berpikir dengan rasional, berperasaan, dan beraspirasi. Hal ini tergambar dari sikapnya yang lemah lembut dan bijaksana. Sikap bijaksana Adilah terlihat ketika ia berpendapat bahwa cucu pertamanya harus memiliki pengasuh seorang ibu yang baik, sehingga ia berinisiatif untuk menikahkan Sabir dengan Majidah. Ia sendiri yang menentukan Majidah sebagai wanita pilihannya untuk menjadi istri Sabir.

Adilah juga meminta pertimbangan Badawi mengenai pernikahan antara Sabir dan Majidah. Adilah kemudian diberi saran oleh Badawi untuk tidak memberitahukan pernikahan Sabir dengan Margaret kepada Majidah. Akan tetapi, Adilah memilih untuk bersikap jujur dan terbuka dan mengabarkan kepada Majidah bahwa Sabir sudah menikah dengan Margaret di Wina. Akan tetapi, Majidah tetap bersedia menikah dengan Sabir walaupun menjadi yang istri yang ketiga (Mansour 1994, 76).

Dari segi sosial-ekonomi, citra Adilah sebagai wanita hampir sama dengan citra Tahani sebagai ibu rumah tangga dan tergantung secara ekonomi kepada suaminya. Adilah yang merupakan istri dari Abdul Latif digambarkan tidak bekerja dan hanya mendampingi Majidah dan cucunya di Mesir (Mansour, 1994, 109-110). Ia dan Majidah keudian pindah ke rumah milik ayah Majidah di pinggir sungai Nil. Mereka berdua bersama-sama merawat anak Sabir di sana (Mansour 1994, 65).

Sebagaimana Margaret dan Majidah, Adilah juga memiiliki citra sebagai seorang wanita terhormat, setidaknya dalam pandangan orng-orang Mesir. Ini karena Adila adalah seorang ibu yang taat beragama dan berhasil mendidik anaknya, yaitu Sabir, sehingga bisa menjadi laki-laki dewasa yang juga taat beragama. Citra Adilah sebagai wanita terhormat ini juga terlihat dari kepatuhan masyarakat kepadanya. Ketika anak laki-lakinya menikah dengan Majidah, orang-orang Mesir di sekitar Sabir mengungkapkan pendapatnya kepada Adilah sekaligus turut bekerjasama dalam menyembunyikan fakta dari pengetahuan Margaret bahwa Sabir telah menikah dengan Majidah (Mansour 1994, 75).

Liliyan

Liliyan sebagai tokoh wanita kelima di dalam novel juga digambarkan memiliki paras yang cantik (Mansour, 1994, 46). Meskipun tidak mempunyai anak, Liliyan diceritakan sebagai wanita yang memiliki jiwa keibuan karena ia berpendapat bahwa kasih sayang ibu adalah hak semua anak (Mansour 1994, 54).

Sebagai sosok yang mampu berpikir dan memiliki perasaan, Liliyan sangat peduli dengan teman-temannya. Diceritakan ia terlibat dalam percakapan dengan Sabir, Badawi, dan Fauzi untuk mengungkapkan pendapatnya mengenai pernikahan Sabir dan Margaret. Ia berpikir dan memberikan solusi, yaitu Sabir harus mengatakan sejujurnya kepada Tahani bahwa ia telah menikah dengan Margaret di Wina. Liliyan juga mengatakan bahwa Sabir harus membawa Margaret ke Mesir jika keduanya sudah bersepakat (Mansour 1994, 47).

Berbeda dengan Adilah dan Majidah, Liliyan dicitrakan sebagai seorang istri sekaligus wanita yang bekerja dan menghasilkan uang. Ia tidak menggantungkan kehidupannya secara ekonomis kepada laki-laki karena ia bekerja sebagai peneliti sosial di Wina (Mansour 1994, 46).

Liliyan adalah wanita Wina yang menikah dengan Fauzi. Dalam kehidupan rumah tangganya, Liliyan selalu penuh perhatian dan waspada kepada suaminya karena, suaminya pernah mepermainkan wanita-wanita lain di Wina. Walaupun demikian, Liliyan tetap melakukan kewajibannya sebagai seorang istri, yaitu mengurusrumah tangga dan mematuhi perintah suaminya (Mansour 1994, 45).

\section{Ideologi Citra Wanita Arab dan Eropa}

Novel Illa Fatimah menampilkan citra wanita dari dua negara dan benua yang berbeda, yaitu Mesir di Afrika dan Austria di Eropa. Mesir merupakan negara anggota Liga Arab yang mengakui bahasa Arab sebagai bahasa resmi negara (Nuraeni, 2010, 306) 
sedangkan Austria merupakan salah satu negara yang terletak di benua Eropa (Ilmu Geografi). Kedua negara ini sedikit banyak bisa merepresentasikan citra wanita di benua masing-masing, yaitu Arab dan Eropa.

Wanita Arab dan Eropa masing-masing memiliki peran gender yang berbeda karena sifat mereka yang dinamis, yaitu tumbuh dan menyesuaikan dengan kenyataan yang ada di lingkungan masyarakat mereka (Puspitawati, 2012, 1). Oleh karena itu, pembahasan ideologi ini akan dibagi menjadi dua, yaitu ideologi citra wanita Arab dan ideologi citra wanita Eropa.

Citra diri wanita Arab secara fisik sebagaimana diceritakan dalam novel IIIa Fatimah dapat dilihat pada Tabel 1.

Tabel 1: Citra Wanita Arab secara Fisik

\begin{tabular}{cl}
\hline \multicolumn{1}{c}{ Tokoh } & \multicolumn{1}{c}{ Penokohan secara Fisik } \\
\hline Majidah & $\begin{array}{l}\text { Wanita Mesir yang berusia sekitar 30 tahun, berwajah cantik, berbola } \\
\text { mata hijau, memiliki hidung yang kecil, berambut pirang, dapat hamil, } \\
\text { melahirkan dan mengasuh anak dengan baik }\end{array}$ \\
Tahani & $\begin{array}{l}\text { Wanita Mesir yang berusia sekitar 20 tahun, dapat hamil, melahirkan } \\
\text { dan mengasuh anak dengan baik }\end{array}$ \\
Adilah & $\begin{array}{l}\text { Wanita Mesir yang berusia sekitar 50 tahun, dapat hamil, melahirkan } \\
\text { dan mengasuh anak dengan baik }\end{array}$ \\
\hline
\end{tabular}

Sementara itu, citra diri wanita Eropa dari aspek yang sama dapat diamati pada Tabel 2.

Tabel 2: Citra Wanita Eropa secara Fisik

\begin{tabular}{ll}
\hline \multicolumn{1}{c}{ Tokoh } & \multicolumn{3}{c}{ Penokohan secara Fisik } \\
\hline Margaret & $\begin{array}{l}\text { Wanita Wina yang berusia sekitar 40 tahun, berwajah cantik, } \\
\text { memiliki bola mata biru, berkulit putih kemerah-merahan, } \\
\text { hidungyang mancung, tidak dapat hamil, namun berjiwa keibuan. }\end{array}$ \\
Liliyan & $\begin{array}{l}\text { Wanita Winayang berwajah cantik, berjiwa keibuan dan tidak } \\
\text { dikaruniai anak }\end{array}$ \\
\hline
\end{tabular}

Berdasarkan kedua tabel di atas, dapat disimpulkan bahwa citra fisik wanita Arab dan Eropa tidak terlalu berbeda, karena keduanya memiliki wajah cantik dan berjiwa keibuan. Namun, ada satu perbedaan yang tampak yaitu dalam hal kemampuan reproduksi. Dalam hal ini, Majidah, Tahani, dan Adilah, selaku wanita Arab, dapat menghasilkan keturunan atau penerus keluarga. Ini berbeda dengan Margaret dan Liliyan yang dicitrakan sebagai wanita Eropa yang mandul atau tidak dapat menghasilkan keturunan.

Perbedaan di atas menghasilkan ideologi atau pandanga mengenai wanita Arab dan Eropa dari sudut pandang pengarang novel, yang dalam hal ini adalah seorang laki-laki dari bangsa Arab, Anis Mansour. Pengarang mencitrakan wanita ideal sebagai wanita yang berparas cantik dan berjiwa keibuan. Khus untuk wanita Arab, soosok ideal ini dilengkapi dengan kemampuan untuk dapat menghasilkan keturunan dengan baik sebagai penerus keluarga. Dengan kata lain, apabila seorang wanita Arab mandul atau tidak bisa memberikan keturunan, maka wanita tersebut tidak dianggap sebagai wanita seutuhnya dan bahkan bisa menjadi aib bagi keluarganya. Berkebalikan dengan wanita Arab, wanita Eropa dicitrakan secara lebih dinamis di mana menghasilkan keturunan bukanlah sesuatu yang wajib bagi mereka.

Dari segi psikis, juga terdapat perbedaan citra antara wanita Arab dan Eropa. Citra wanita Arab secara psikis ditunjukkan pada Tabel 3. 


\begin{tabular}{|c|c|}
\hline Tokoh & Penokohan secara Psikis \\
\hline Majidah & $\begin{array}{l}\text { Wanita yang mampu berpikir, penurut dan berperasaan, namun } \\
\text { tidak berani mengungkapkan perasaan atau emosi secara langsung } \\
\text { kepada laki-laki }\end{array}$ \\
\hline Tahani & $\begin{array}{l}\text { Wanita yang mampu berpikir dan berperasaan, namun tidak berani } \\
\text { mengungkapkan perasaan atau emosi secara langsung kepada laki- } \\
\text { laki }\end{array}$ \\
\hline Adilah & $\begin{array}{l}\text { Wanita yang mampu berpikir, berperasaan dan beraspirasi untuk } \\
\text { mengungkapkan pendapat dan menikahkan anak laki-lakinya. }\end{array}$ \\
\hline
\end{tabular}

Sementara itu, citra wanita Eropa dari aspek yang sama dapat dibandingkan sebagimana tampak pada Tabel 4 .

\section{Tabel 4: Citra Wanita Eropa Secara Psikis}

\begin{tabular}{ll}
\hline \multicolumn{1}{c}{ Tokoh } & \multicolumn{1}{c}{ Penokohan secara Psikis } \\
\hline Margaret & $\begin{array}{l}\text { Wanita yang mampu berpikir dan berperasaan, namun dapat } \\
\text { mengungkap perasaan dan emosi secara langsung kepada laki-laki }\end{array}$ \\
Liliyan & $\begin{array}{l}\text { Wanita adalah makhluk psikologis yang mampu berpikir dan } \\
\text { berperasaan. Ia dapat mengungkapkan pendapatnya kepada laki-laki }\end{array}$ \\
\hline
\end{tabular}

Dari aspek psikologis, wanita Arab merupakan wanita yang mampu berpikir, berperasaan, beraspirasi, tetapi penurut kepada laki-laki. Akan tetapi, mereka tidak dibenarkan mengungkapkan perasaan dan pendapatnya secara langsung kepada lakilaki. Berkebalikan dengan wanita Arab, wanita Eropa adalah wanita yang berani mengungkapkan emosinya secara langsung kepada laki-laki. Wanita Arab dan Eropa memiliki citra wanita yang berkebalikan dalam aspek psikologis.

Perbedaan citra wanita di atas sedikit banyak membuktikan bahwa di negara Arab, peran laki-laki atau paham patriarki sangat kuat. Wanita dianggap tidak layak untuk menduduki pekerjaan atau jabatan yang sama dengan laki-laki, sehingga wanita Arab tidak mampu untuk mengungkapkan perasaan dan cenderung penurut kepada laki-laki. Berbeda dengan wanita Eropa yang mendapatkan hak kesetaraan gender, sehingga mereka dapat menduduki pekerjaan dan meiliki martabat yang sama dengan laki-laki.

Selanjutnya, ideologi citra sosial wanita Arab dan Eropa dibagi menjadi dalam dua ruang lingkup, yakni keluarga dan masyarakat. Tabel 5 memperlihatkan citra sosial wanita Arab dalam keluarga.

\section{Tabel 5: Citra Sosial Wanita Arab dalam Keluarga}

\begin{tabular}{cl}
\hline Tokoh & \multicolumn{1}{c}{ Penokohan secara Sosial dalam Keluarga } \\
\hline Majidah & $\begin{array}{l}\text { Wanita tidak bekerja dan bergantung kepada laki-laki secara ekonomis, } \\
\text { serta bertugas mengurus kerumahtanggaan }\end{array}$ \\
Tahani & $\begin{array}{l}\text { Wanita tidak bekerja dan bergantung kepada laki-laki secara ekonomis, } \\
\text { serta bertugas mengurus kerumahtanggaan }\end{array}$ \\
Adilah & Wanita yang bertugas mengurus kerumahtanggaan \\
\hline
\end{tabular}

Sementara itu, citra sosial wanita pada ruang lingkup yang sama dapat dilihat pada Tabel 6. 
Tabel 6: Citra Sosial Wanita Eropa dalam Keluarga

\begin{aligned} & \hline Tokoh \multicolumn{1}{c}{ Penokohan secara Sosial dalam Keluarga } \\ & \hline Margaret $\begin{array}{l}\text { Wanita yang tidak bergantung kepada laki-laki secara ekonomis dan } \\ \text { dapat mengurus rumah tangga dengan baik }\end{array} \\ &$ Liliyan Wanita yang tidak bergantung kepada laki-laki secara ekonomis \\ & \hline\end{aligned}

Berdasarkan analisis ideologi citra sosial wanita dalam keluarga sebagaiamana disajikan dalam di atas, wanita Arab merupakan wanita yang hanya fokus menjadi istri, ibu rumah tangga yang baik, tidak bekerja, dan bergantung kepada laki-laki secara ekonomis dan bahkan rela ditinggal suaminyauntuk mencari nafkah di luar negeri. Sementara itu, wanita Eropa adalah wanita memiliki karir, tidak bergantung kepada lakilaki dalam hal ekonomi, dan merupakan istri yang baik dalam keluarga.

Citra sosial wanita Arab dan Eropa ini ternyata sejalan dengan citra psikis yang telah dipaparkan sebelumya, yaitu di negara-negara Arab wanita tidak pantas melakukan pekerjaan, karena bekerja adalah tugas laki-laki. Inilah ang mengakibatkan wanita Arab bergantung secara ekonomis kepada laki-laki. Sebaliknya, di Eropa wanita lebih mandiri dan dapat bekerja dengan bebas sehingga kehidupana ekonomi mereka tidak tergantung kepada laki-laki,

Di sisi lain, ada juga beberapa perbedaan citra sosial antara wanita Arab dan Eropa di masyarakat. Citra sosial wanita Arab di masyarakat dapat diamati pada Tabel 7.

Tabel 7: Citra Sosial Wanita Arab di Masyarakat

\begin{tabular}{cl}
\hline Tokoh & \multicolumn{1}{c}{ Penokohan secara Sosial di Masyarakat } \\
\hline Majidah & $\begin{array}{l}\text { Wanita yang dicitrakan sebagai seorang wanita yang dihormati di } \\
\text { masyarakat karena menikah dengan laki-laki yang dihormati karena taat } \\
\text { beragama di lingkungan tersebut }\end{array}$ \\
Tahani & $\begin{array}{l}\text { (Tidak digambarkan dalam novel) } \\
\text { Adilah }\end{array}$ \\
& $\begin{array}{l}\text { Wanita yang dihormati oleh masyarakat, khususnya orang-orang Mesir } \\
\text { karena mampu mendidik seorang anak yang dihormati karena taat } \\
\text { beragama di lingkungan tersebut. }\end{array}$ \\
\hline
\end{tabular}

Sementara itu, citra sosial wanita Eropa dalam Masyarakat ditunjukkan melalui Tabel 8.

Tabel 8: Rangkuman Citra Sosial Wanita Eropa dalam Masyarakat

\begin{tabular}{ll}
\hline \multicolumn{1}{c}{ Tokoh } & \multicolumn{1}{c}{ Penokohan secara Sosial di Masyarakat } \\
\hline $\begin{array}{l}\text { Margaret } \\
\text { Liliyan }\end{array}$ & Wanita yang kaya raya di mata masyarakat sekitarnya. \\
(Tidak digambarkan dalam novel)
\end{tabular}

Perbedaan citra sosial antar wanita Arab dan wanita Eropa di masyarakat terletak pada apa yang dimilikinya. Wanita Arab akan dipandang dan dihormati oleh masyarakat apabila memiliki suami atau anak laki-laki yang terhormat sedangkan wanita Eropa dihormati oleh masyarakat karena harta kekayaannya.

Dari apa yang disajikan pada tabel, terlihat bahwa dalam kehidupan masyarakat di negara-negara Arab, wanita tidak akan mendapatkan kedudukan yang terhormat apabila tidak memiliki suami atau keturunan laki-laki yang juga terhormat. Hal ini merupakan pengaruh budaya patriarki yang kuat di negara-negara Arab. Di Arab, walaupun seorang wanita memiliki paras cantik dan sifat mulia, jika tidak taat suami dan tidak memiliki keturunan, ia tidak akan dianggap dalam kehidupan di masyarakat. Sebaliknya, wanita 
Eropa sangat menjunjung tinggi kesetaraan gender sekaligus menentang budaya patriarki dalam masyarakat sehingga mereka lebih bebas untuk mengekspresikan diri.

\section{KESIMPULAN}

Berdasarkan analisis yang telah dilakukan, tokoh dalam novel Illa Fatimah dapat dibagi menjadi dua, yaitu tokoh utama dan tokoh tambahan. Tokoh utama dalam novel tersebut adalah seorang laki-laki yang bernama Sabir sedangkan tokoh tambahannya adalah Margaret, Majidah, Tahani, Liliyan, dan Adilah dari kelompok wanita sedangkan Badawi, Irfan, Fauzi, dan Abdul Latif dari kelompok laki-laki.

Tokoh wanita dalam novel Illa Fatimah berperan aktif dalam kehidupan sehariuhari tokoh utama. Majidah, Tahani, dan Adilah adalah wanita yang berasal dari Arab, sedangkan Margaret dan Liliyan digambarkan sebagai wanita yang berasal dari Eropa. Tokoh-tokoh wanita tersebut merepresentasikan citra wanita dari tempat asal mereka.

Wanita Arab dan wanita Eropa menampakkan citra yang berbeda. Secara keseluruhan, citra wanita Arab telah dipengaruhi oleh budaya patriarki yang kuat yang dibuktikan dibuktikan dengan adanya dominasi laki-laki dalam aspek psikologis dan sosial, baik di lingkungan keluarga maupun masyarakat. Wanita Arab tidak diperkenankan untuk bekerja dan bergantung kepada laki-laki sepenuhnya dalam hal ekonomi. Selain itu, masalah keturunan juga sangat berengaruh pada citra wanita Arab di lingkungan keluarga. Melalui novel ini, Anis Mansour menyampaikan kritik feminisnya sebagai seorang Arab muslim. Ia menentang adanya subordinasi dan diskriminasi terhadap wanita di negara-negara Arab di mana budaya patriarki masih mendominasi. Mansour menjunjung tinggi kemuliaan wanita sesuai dengan ajaran agama Islam.

Sebaliknya, wanita Eropa dicitrakan sebagai wanita yang mandiri dan menentang budaya patriarki. Mereka dibebaskan untuk mengekspresikan diri dan bekerja layaknya laki-laki. Dalam kaitannya dengan aspek keluarga, meiliki keturunan bukanlah hal yang penting. Dari sudut pandang pengarang, di Eropa, seorang wanita akan dianggap memiliki martabat di lingkungan masyarakat, apabila ia memiliki karier dan menghasilkan kekayaan. Dalam hal ini, laki-laki tidak berpengaruh terhadap kesuksesan wanita di masyarakat.

\section{DAFTAR PUSTAKA}

Aljazeera Encyclopedia. 2020. "Anis Mansour, al-Adab wa As-Sohafah wa asSiyasah”.https://www.aljazeera.net/encyclopedia/icons/2017/1/26/ أنيس-منصور -الأدب-والصحافة "26) (Diakses 3 April 2020)

Ashidqy Muhammad Fahmy. 2017. "Ketidakadilan Gender Dalam Fatatun min Dimasyqa" antologi 'Alwanun Minal Hubbi' karya Anis Mansour : Analisis Kritik Sastra Feminis". Skripsi. Jurusan Sastra Arab. Fakultas Ilmu Budaya. Universitas Gadjah Mada. http://etd.repository.ugm.ac.id/index.php?mod=penelitian_detail\&sub=PenelitianDetail\&ac $\mathrm{t}=$ view\&typ=html\&buku_id=110064\&obyek_id=4. (Diakses 2 April 2021)

Ayyaz, Ahmad._ 'Anis Mansour: A Critical Study of His Writings on Travelogue and Autobiography'. Disertasi. Program Studi Sastra Arab. Universitas Baba Gulm Shah Padshah. http://shodh.inflibnet.ac.in:8080/jspui/bitstream/123456789/1339/1/synopsis. pdf. (Diakses 2 April 2021)

Djajanegara Soenarjati. 2000. Kritik Sastra Feminis: Sebuah Pengantar. Jakarta: Gramedia

Egypt Independent. 2020 "Politics and culture in the life of Anis Mansour". https://www.egyptindependent.com/politics-and-culture-life-anis-Mansour/(Diakses $\quad 18$ September 2020)

Fauziyah, Mufidatun. 2015. "Unsur-unsur Intrinsik Cerpen "Garamun Fi At-Tilifun" dalam antologi cerpen 'Qulubun Sagiratun' Karya Anis Mansour: Analisis Struktural Robert Stanton". (Skripsi) Yogyakarta: Jurusan Sastra Asia Eropa. Fakultas Ilmu Budaya. Universitas Gadjah Mada

Ilmu Geografi. 2020. "Karateristik Benua Eropa Paling Lengkap". https://ilmugeografi.com/ ilmu-bumi/benua/karakteristik-benua-eropa. (Diakses 28 September 2020) 
Mansour, Anis. 1993. Illa Fatimah. Beirut: Darussyuruq

Muslimat.1990. "Citra Perempuan dalam Novel-Novel Indonesia Tahun 200-an". Jurnal Sastra Indonesia. Makassar: Fakultas Ilmu Budaya Universitas Hasanuddin.

Nuraeni S, dkk. 2010. Regionalisme Dalam Studi Hubungan Internasional. Yogyakarta : Pustaka Pelajar

Nurgiyantoro, Burhan. 1996. Teori Pengkajian Fiksi. Yogyakarta: Gadjah Mada University Press

Omara, Andy. 2004. "Perempuan, Budaya Patriarki dan Representasi”. Jurnal. Mimbar Hukum. http://i-lib.ugm.ac.id/jurnal/detail.php?dataId=2625. (Diakses2 April 2021)

Puspitawati, H. 2013. "Konsep, Teori dan Analisis Gender". Jurnal Departemen Ilmu Keluarga dan Konsumen Fakultas Ekologi Manusia. Bogor: Institut Pertanian Bogor. http://ikk.fema.ipb.ac.id/v2/images/karyailmiah/gender.pdf.(Diakses 2 April 2021)

Revolvy. 2018. “Anis Mansour”.https://www.revolvy.com/page/Anis-Mansour. (Diakses 18 September 2018)

Sudaryanto. 2015. Metode dan Aneka Teknik Analisis Bahasa. Yogyakarta: Sanata Dharma University Press

Sudjiman, Panuti. 1986. Kamus Istilah Sastra. Jakarta: Gramedia

Sugihastuti, 2000. Wanita di Mata Wanita. Bandung: Nuansa

Sugihastuti Suharto. 2016. Kritik Sastra Feminis Teori dan Aplikasinya. Cet. 6. Yogyakarta: Pustaka Pelajar

Teeuw, A, 1984. Sastra dan Ilmu Sastra: Pengantar Teori Sastra. Jakarta: Pustaka Jaya

Upclosed. 2020. "Biography of Anis Mansour". https://upclosed.com/people/anis-Mansour/. (Diakses 18 September 2020)

Wiyatmi, 2009. Pengantar Kajian Sastra. Yogyakarta: Pustaka Book Publisher 